\title{
The influence of Fusarium infection and growing location on the quantitative protein composition of (part I) emmer (Triticum dicoccum)
}

\author{
Kai Eggert · Herbert Wieser · Elke Pawelzik
}

Received: 19 November 2009 / Revised: 4 January 2010 / Accepted: 16 January 2010 / Published online: 16 February 2010

(C) The Author(s) 2010. This article is published with open access at Springerlink.com

\begin{abstract}
The effect of the fungal infection by Fusarium graminearum and Fusarium culmorum of emmer and wheat cultivars on their total protein content and the protein fractions albumins + globulins, gliadins and glutenins and their different protein types was investigated. In addition, the influence of two different locations on the quantitative protein composition was evaluated. The results showed that Fusarium infection changed the content of gliadins and glutenins in emmer and wheat. The wheat glutenin fractions and types were found to be more strongly affected by the Fusarium spp. infection than the glutenin fractions and types in emmer cultivars in spite of the wheat's lower degree of infection. The nitrogen supply at the two locations was associated with an increase in the gliadin content in emmer and an increase in the glutenin content in emmer and wheat. Nitrogen availability, a factor which promotes gene expression, resulted here in a species-specific effect on the gliadin/glutenin ratio.
\end{abstract}

Keywords Emmer $\cdot$ Fusarium $\cdot$ Fusarium protein units (FPU) $\cdot$ ELISA $\cdot$ Deoxynivalenol $\cdot$ LC-MS/MS

\section{Abbreviations \\ ALG Albumins and globulins \\ FPU Fusarium protein units}

K. Eggert $(\bowtie) \cdot$ E. Pawelzik

Section Quality of Plant Products,

Department of Crop Sciences, Faculty of Agricultural Sciences,

Georg-August University, 37075 Göttingen, Germany

e-mail: keggert@gwdg.de

H. Wieser

German Research Centre of Food Chemistry,

85748 Garching, Germany
HMW-GS High molecular weight glutenin subunits

LMW-GS Low molecular weight glutenin subunits

PR proteins Pathogenesis-related proteins

$p \quad$ Significance factor

RT Room temperature

TFA Trifluoroacetic acid

\section{Introduction}

Fusarium graminearum and Fusarium culmorum infection of cereal grains (such as wheat, barley and emmer) leads to pathogenic effects on the plant and spike. These can result in dramatic yield and quality losses [1, 2]. Fusarium head blight (FHB) is the visible effect of this fungal infection and is a problem known throughout the world [1, 3, 4]. These two Fusarium species are producers of trichothecene mycotoxins such as deoxynivalenol, 3- and 15-acetyldeoxynivalenol (3-Ac-DON and 15-Ac-DON, respectively; major DON precursors) and others [1]. The trichothecene mycotoxins are potential inhibitors of protein biosynthesis. In mammals, they lead to unspecific effects in the intestine causing diarrhoea, vomiting, a reduced food intake and a raised bleeding tendency of the intestines. Their more specific effects include reduced leucocyte content connected with a loss of the immune function and an increase in free radicals in the liver [5-8].

Emmer (Triticum dicoccum) cultivars are normally grown in organic farming systems. At the moment, little knowledge exists about the influence of Fusarium infection on the protein fractions in this species. The total protein content is documented for emmer at around $12-13 \%$ of dry mass [9]. The influence of Fusarium infection on grain protein composition has been mainly investigated in wheat cultivars. The results from these investigations have suggested 
that depending on infection degree, no impact on total protein content could be observed or just moderately increased concentrations of total protein could be documented [10, 11]. However, an influence on protein fractions, such as an increase in gliadin and a reduction in glutenin content, has also been recorded. A change in the synthesis behaviour at different maturation stages has been postulated as an explanation for this observation [11]. Studies focusing on the synthesis of cereal seed storage proteins did not show any alterations in the synthesis stages during grain maturation; only a belated polymerization of glutenins was noted [12]. An influence of Fusarium infection on LMW glutenin degradation has been shown in a study which focused on suboptimal storage conditions [13].

The total protein content in wheat cultivars is also increased by increasing the nitrogen supply. The sizes of the gliadin and glutenin fractions are also changed. However, nitrogen has apparently no influence on the albumin and globulin fractions $[14,15]$. It is not known how emmer reacts to increasing the supply of nitrogen.

The presented study focuses on the influence of artificial Fusarium infection on the Osborne protein fractions and single protein types in emmer in comparison to naturally infected samples. Our investigations were done on harvested grains to determine the conditions in fully developed grains. In addition, the effect of two different locations on the content of total protein and protein fractions and types was also monitored. Finally, the question as to what modifications of protein composition and protein synthesis occur in connection to nitrogen availability and exposition to Fusarium infection was addressed. A wheat cultivar was used for comparison.

\section{Materials and methods}

Experimental design and sample preparation

Three emmer cultivars (Linie 9-102, Far-108+Hein-101, Klein) and for comparison, one summer wheat (Amaretto) cultivar grown in two field trials at Reinshof (RH) [16] and Sattenhausen (SH) in the centre of Germany near Göttingen were randomized with eight replications. In each block, the second row was artificially inoculated with a mixed $F$. culmorum and $F$. graminearum spore suspension $\left(50 \mathrm{ml} / \mathrm{m}^{2} ; 1 \times 10^{5}\right.$ spores $\left./ \mathrm{ml}\right)$ three times during flowering. Three DON-producing strains of $F$. culmorum (FC34, FC35, FC36) and $F$. graminearum (FG142, FG143, FG144) were used for conidiospore production. Only 3-AcDON could be detected in these strains, not 15-Ac-DON. After harvest, the grain without inoculation (natural infection) and with inoculation (artificial infection) from the plots (four replications each) from each field trial was mixed. Whole grain flour was obtained by milling (Retsch ZM 100, Haan, Germany) at a particle size of $0.5 \mathrm{~mm}$.

The location conditions at RH [16] are $152 \mathrm{~m}$ above sea level, wind sheltered and dale area near a river border. The $\mathrm{N}_{\text {min }}$ content was $145 \mathrm{~kg} / \mathrm{ha}$ recorded in $90-\mathrm{cm}$ depth dry soil. At SH, the conditions are $260 \mathrm{~m}$ above sea level, hilly and windy. The $\mathrm{N}_{\min }$ content was $95 \mathrm{~kg} / \mathrm{ha}$ in $90-\mathrm{cm}$ dry soil with an additional fertilization of $40 \mathrm{~kg} \mathrm{~N} / \mathrm{ha} 2$ months after sowing.

Quantitative LC-MS/MS of Fusarium mycotoxin DON and 3-Ac-DON

Whole grain flour $(5 \mathrm{~g})$ was extracted with $40 \mathrm{ml}$ of an acetonitrile-water mixture $(80: 20)$ over night on a reciprocal shaker. The extracts were centrifuged for $12 \mathrm{~min}$ at 5,000g and $4 \mathrm{ml}$ of the supernatant were used for solid-phase extraction (Bond-Elut Mycotoxin, Varian GmbH, Darmstadt, Germany) according to the manufacturer's instructions. Two millilitres of the cleaned extract were evaporated to dryness under vacuum, redissolved in $200 \mu \mathrm{l}$ of methanol-water (50:50) containing $0.2 \mathrm{mmol}$ ammonium acetate and $10 \mu \mathrm{l}$ of the solution was injected onto a C18 column $(100 \times 2 \mathrm{~mm}, 3-\mu \mathrm{m}$ particle size $)$ filled with polar-modified material (Polaris Ether, Varian $\mathrm{GmbH}$, Darmstadt, Germany). The analytes were eluted with a methanol-water gradient (15-70\% over $20 \mathrm{~min}$ ) containing $0.2 \mathrm{mmol}$ ammonium acetate at a flow rate of $0.2 \mathrm{ml} / \mathrm{min}$. DON and 3-Ac-DON were detected by tandem mass spectrometry as described by Adejumo et al. [17].

Quantitative nitrogen analysis

The nitrogen content was quantitatively measured with a $\mathrm{C} / \mathrm{N}$ analyser (Vario MAX CN Elementar Analysesysteme GmbH, Hanau, Germany). A 100-mg dry sample for each emmer and wheat cultivar was analysed for its $\mathrm{N}$ content. This was converted to protein using the factor 5.7 for both the emmer and wheat (ICC No. 105/2).

Quantification of Fusarium protein units (FPU)

Biotin/Avidin ELISA, a double-antibody sandwich with rabbit-anti-fungal antibody, was performed to detect the soluble FPU in $\mathrm{mg} / \mathrm{kg}$ using 96-well convex-bottomed plates (Immuno Plate Maxisorb, Nunc International, Denmark) and a photometer (Spectra II, SLT Laborinstruments, Austria). The FPU were extracted from the milled grain with 20 times of buffer quantity $[0.01 \mathrm{~mol} / \mathrm{l}$ phosphate buffer $+0.05 \%(\mathrm{v} / \mathrm{v})$ Tween $20(\mathrm{PBST})$ and $1 \%$ polyvinylpolypyrrolidone (PVP) $\mathrm{pH} 7.2$ ] by shaking for $12 \mathrm{~h}$ at $4{ }^{\circ} \mathrm{C}$. The extract was centrifuged $(12,000 \mathrm{~g} / 4 \mathrm{~min})$ and the supernatant was used for ELISA. 
To prepare the micro-wells, $100 \mu \mathrm{lgG}$ in $0.05 \mathrm{M}$ carbonate buffer/loading buffer $\left[\mathrm{Na}_{2} \mathrm{CO}_{3} / \mathrm{NaHCO}_{3}\right] \mathrm{pH} 9.6$ was placed in each cavity and the antibodies were immobilized on the surface during an incubation time of $12 \mathrm{~h}$ at $4{ }^{\circ} \mathrm{C}$. The wells were then washed three times for $3 \mathrm{~min}$ with $100 \mu \mathrm{l}$ washing buffer (1/1 PBST/dest. $\mathrm{H}_{2} \mathrm{O}$ v/v), and dried by beating the wells gently on a paper towel. To block nonspecific binding, $200 \mu 1 \%$ (w/v) defatted milk powder in loading buffer was added and incubated for $1 \mathrm{~h}$ at $37^{\circ} \mathrm{C}$. The wells were washed again. Following this, $100 \mu \mathrm{l}$ of sample extract was added and incubated for $12 \mathrm{~h}$ at $4{ }^{\circ} \mathrm{C}$. The wells were washed again. In the next step, $100 \mu \mathrm{l}$ biotinylated antibodies in binding buffer $[0.2 \%(\mathrm{w} / \mathrm{v})$ BSA + PBST, pH 7.2] were added and incubated for $12 \mathrm{~h}$ at $4{ }^{\circ} \mathrm{C}$. The wells were then washed as described in the steps before. Subsequently, $100 \mu$ streptavidin alkaline phosphatase [dissolved 1:10,000 (v/v) in binding buffer] was added to each well and incubated for $1 \mathrm{~h}$ at room temperature, following which, the washing step was repeated. Finally, $100 \mu \mathrm{l}$ buffer $(1 \mathrm{mg} / \mathrm{ml} \mathrm{p}$-nitrophenyl phosphate in diethanolamine buffer, $\mathrm{pH}$ 9.8) was added and incubated at room temperature for $2 \mathrm{~h}$. The absorption was then measured at $450 \mathrm{~nm}$ (with reference at $592 \mathrm{~nm}$ ). For the external standard, cleaned soluble Fusarium protein (F. culmorum/F. graminearum) was used to create a standard row as FPU in $\mathrm{mg} / \mathrm{g}$ sample, with the protein content of the standard being based on a Bradford assay [18]. For analysis of the protein content of the Fusarium standard, cleaned $F$. graminearum was used and the soluble and insoluble fractions were measured with $\mathrm{C} / \mathrm{N}$ analyser.

\section{Quantitative protein analysis with RP-HPLC}

Protein extraction from $100 \mathrm{mg}$ flour samples was realized stepwise. In the first step, $1 \mathrm{ml}$ extraction with solution A [HKNaPO${ }_{4}: 97$ parts $\mathrm{Na}_{2} \mathrm{HPO}_{4}(0.067 \mathrm{~mol} / \mathrm{l})+(0.4 \mathrm{~mol} / \mathrm{l})$ $\mathrm{NaCl}$ and 3 parts $\mathrm{KH}_{2} \mathrm{HPO}_{4}(0.067 \mathrm{~mol} / \mathrm{l})+(0.4 \mathrm{~mol} / \mathrm{l})$ $\mathrm{NaCl}$; $\mathrm{pH}$ 7.6)] by vortexing for $2 \mathrm{~min}$ and shaking at room temperature for $10 \mathrm{~min}$ for the albumin/globulin fractions was repeated twice. The samples were centrifuged for $20 \mathrm{~min}$ at $6,000 \mathrm{~g}$ and the supernatants were combined and filled up to $2 \mathrm{ml}$. The pellet was then extracted three times with $0.5 \mathrm{ml}$ extraction solution B [60\% ethanol (v/v)], vortexed for $2 \mathrm{~min}$ and exposed to $10 \mathrm{~min}$ of shaking at room temperature. The samples were subsequently centrifuged for $20 \mathrm{~min}$ at $6,000 \mathrm{~g}$ and the gliadin-containing supernatants were combined and filled up to $2 \mathrm{ml}$. In the third step, the remaining pellet was extracted two times with $1 \mathrm{ml}$ extraction solution C [50\% 1-propanol (v/v)/2 mol/l urea, $0.05 \mathrm{~mol} / \mathrm{l} \mathrm{Tris} / \mathrm{HCl}(\mathrm{pH} 7.5)+1 \%$ dithioerythritol (DTE)] under $\mathrm{N}_{2}$, with $2 \mathrm{~min}$ vortexing and $30 \mathrm{~min}$ shaking at $60{ }^{\circ} \mathrm{C}$. The samples were centrifuged for $20 \mathrm{~min}$ at $6,000 \mathrm{~g}$ and these glutenin-containing supernatants were combined and filled up to $2 \mathrm{ml}$. All the extracts were filtered with a $0.45-\mu \mathrm{m}$ filter: FP 30/0.45 CA Whatman (schleicher + schuell, Germany) before HPLC injection.

For the RP-HPLC, a Nucleosil 300-5 C8 $250 \times 4.6$ silica column (Macherey-Nagel, Dueren, Germany) was used. As mobile phases, $\mathrm{A}=0.1 \%$ TFA in $\mathrm{H}_{2} \mathrm{O}(\mathrm{v} / \mathrm{v})$ and $\mathrm{B}=0.1 \%$ TFA in acetonitrile (v/v) were applied. The flow rate was $1 \mathrm{ml} / \mathrm{min}$ with the column temperature maintained at $50{ }^{\circ} \mathrm{C}$. For the detection of albumins/globulins, $150 \mu \mathrm{l}$ of sample solution was injected and separated using the following gradient: $0 \mathrm{~min}, 20 \% \mathrm{~B} ; 20 \mathrm{~min}, 60 \% \mathrm{~B}$; whereas for the gliadins and glutenins, $50 \mu \mathrm{l}$ and $100 \mu \mathrm{l}$ were injected, respectively, and the separation was performed by applying the following gradient: $0 \mathrm{~min}, 24 \% \mathrm{~B} ; 50 \mathrm{~min}$, $56 \%$ B [19]. For the quantification of the protein fractions the external PWG (Prolamin Working Group) gliadin standard was used [20] (Fig. 1).

Statistical analyses were performed using Microsoft Excel 2003 for mean value, standard deviation and significance $(p)$.

\section{Results and discussion}

The influence of Fusarium infection on the quantitative protein composition of emmer

The detected fungal content expressed as Fusarium toxin (DON and 3-Ac-DON) in the three emmer cultivars and the wheat cultivar showed a significant increase in all the investigated parameters after artificial infection in comparison to the naturally infected cultivars (Tables 1, 2, 3, 4, 5, 6). This confirms that the two cereals and their tested cultivars were susceptible to Fusarium spp. [2, 4, 21]. The total protein $(\mathrm{N} \times 5.7)$ and the extractable protein content of the two cereals and their cultivars did not change significantly with respect to the Fusarium infection (Table 6). These results are in accordance with an earlier study in which no impact on the total protein content in F. culmorum-infected samples was also found [11]. In contrast, however, older results on $F$. graminearum found a moderate increase in the total protein content depending on the degree of infection [10].

A comparison between emmer and wheat showed a $28 \%$ higher total protein and extractable protein content in emmer (Table 6). A comparison of the total protein content and the amount of extractable protein showed that about $77 \%$ of the total protein content can be extracted by the method used in this study (Tables 1, 2, 3, 4, 5, 6). Nonextractable proteins are membrane associated or integrated basic proteins with a high sugar content [22] and nonextractable storage proteins. For a more complete extraction of the plant proteome, special procedures must be used [23]. 
Fig. 1 RP-HPLC of protein fractions in emmer (Linie 9-102) and wheat (Amaretto). a, d 1, albumins/globulins total; b, e 2, $\omega 5$-gliadins; 3, $\omega 1$ 1,2-gliadins; 4, $\alpha$-gliadins; 5, $\gamma$-gliadins; total gliadin (prolamine) from first to last bar; c, f 6, $\omega$ b-gliadins; 7, HMW-GS; 8, LMW-GS; total glutenin (glutelins) from first to last bar
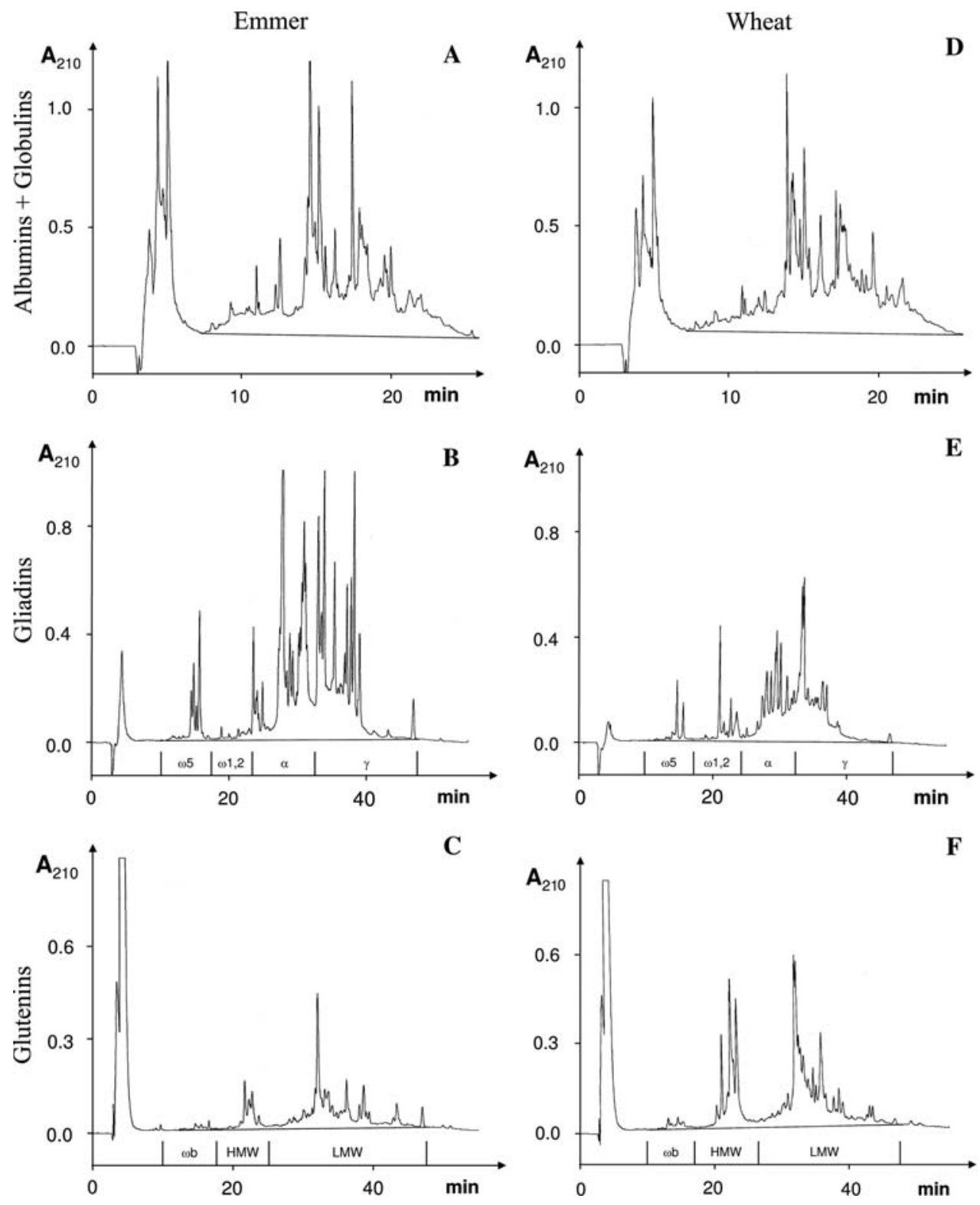

To quantify the contribution of Fusarium protein to the grain's proteins, the amount of soluble $F$. graminearum protein in the grain was determined as this is the most important fungus in Europe. We found 15\% soluble and $85 \%$ insoluble $F$. graminearum protein and a total protein content of $18 \%$ for the fungus. With this information and the amount of soluble FPU detected by ELISA, we could conclude that the proportion of soluble Fusarium protein of the total protein even in strongly infected grains is relatively small: for emmer, a maximum of $0.13 \%$, and for wheat, $0.3 \%$ of the protein was of Fusarium origin (Table 7). A masking of the absolute grain protein content by Fusarium infection and reduced grain protein content due to the Fusarium infection can, therefore, be excluded.

The influence of Fusarium infection on the Osborne fractions in emmer and wheat showed that the albumin and globulin fraction was not significantly changed by the presence of Fusarium infection (Tables 1, 2, 3, 4, 5, 6). Based on the total extractable protein, the albumin and globulin fraction in emmer formed, with $15 \%$, a $6 \%$ lower proportion of the total extractable protein than this fraction in wheat. This may be due either to the higher content of this fraction in wheat in comparison to emmer or to there being a better extractability of gliadin and glutenin in emmer.

The gliadin and glutenin fractions and types were influenced by Fusarium infection (Tables 1, 2, 3, 4, 5, 6). For gliadins, the content of all types increased after artificial infection in comparison to the naturally infected wheat samples (Table 5). In comparison, this effect was less clear in emmer after artificial infection as only the samples from the location RH with the stronger infection degree (based on the amount of Fusarium toxin) showed this effect 
Table 1 Protein concentration $(\mathrm{g} / \mathrm{kg})$ in naturally and artificially Fusarium-infected grain from the emmer cultivar Linie 9-102 and the relative variance between natural and artificial infection (\%) at the locations Sattenhausen and Reinshof as well as the DON and 3-Ac-DON concentration of the naturally and artificially infected grain

\begin{tabular}{|c|c|c|c|c|c|c|c|}
\hline \multirow{2}{*}{$\begin{array}{l}\text { Protein fractions } \\
(\mathrm{g} / \mathrm{kg})\end{array}$} & \multirow[t]{2}{*}{ Type } & \multicolumn{3}{|l|}{ Sattenhausen } & \multicolumn{3}{|l|}{ Reinshof } \\
\hline & & $\begin{array}{l}\text { Natural } \\
\text { infection }\end{array}$ & $\begin{array}{l}\text { Artificial } \\
\text { infection }\end{array}$ & $\begin{array}{l}\text { Variance natural } \\
\text { to natural to } \\
\text { artificial } \\
\text { infection }(\%)\end{array}$ & $\begin{array}{l}\text { Natural } \\
\text { infection }\end{array}$ & $\begin{array}{l}\text { Artificial } \\
\text { infection }\end{array}$ & $\begin{array}{l}\text { Variance natural } \\
\text { to artificial } \\
\text { infection }(\%)\end{array}$ \\
\hline \multirow[t]{3}{*}{ Albumins + globulins } & Total & $21.6 \pm 0.4$ & $21.4 \pm 0.0$ & -1 & $22.3 \pm 1.1$ & $22.0 \pm 1.0$ & -2 \\
\hline & Total & $90.3 \pm 0.9$ & $89.5 \pm 0.6$ & -1 & $118.4 \pm 0.3$ & $119.8 \pm 1.9$ & 1 \\
\hline & $\omega 5$ & $4.0 \pm 0.1$ & $3.8 \pm 0.1$ & -5 & $7.5 \pm 0.1$ & $7.3 \pm 0.2$ & -2 \\
\hline \multirow[t]{5}{*}{ Gliadins } & $\omega 1,2$ & $0.9 \pm 0.1$ & $0.7 \pm 0.1$ & -21 & $1.4 \pm 0.1$ & $1.2 \pm 0.2$ & -17 \\
\hline & $\alpha$ & $39.1 \pm 0.3$ & $38.5 \pm 0.6$ & -1 & $54.7 \pm 0.6$ & $55.3 \pm 1.3$ & 1 \\
\hline & $\gamma$ & $46.3 \pm 0.4$ & $46.5 \pm 0.8$ & 0 & $54.8 \pm 0.6$ & $55.9 \pm 0.2$ & 2 \\
\hline & Total & $13.3 \pm 0.1$ & $11.2 \pm 0.5$ & -16 & $15.7 \pm 0.1$ & $13.9 \pm 0.0$ & -12 \\
\hline & $\omega \mathrm{b}$ & $0.3 \pm 0.0$ & $0.3 \pm 0.1$ & 0 & $0.6 \pm 0.0$ & $0.4 \pm 0.1$ & -33 \\
\hline \multirow[t]{2}{*}{ Glutenins } & HMW-GS & $1.7 \pm 0.2$ & $1.4 \pm 0.1$ & -19 & $2.7 \pm 0.1$ & $2.2 \pm 0.2$ & -18 \\
\hline & LMW-GS & $11.3 \pm 0.3$ & $9.5 \pm 0.6$ & -15 & $12.4 \pm 0.1$ & $11.3 \pm 0.2$ & -9 \\
\hline Gluten & Total & $103.6 \pm 1.0$ & $100.7 \pm 0.1$ & -3 & $134.1 \pm 0.4$ & $133.7 \pm 2.3$ & 0 \\
\hline Gliadin/glutenin & Ratio & 6.8 & 8.0 & - & 7.5 & 8.6 & - \\
\hline Extract proteins & Total & $125.2 \pm 1.4$ & $122.1 \pm 0.1$ & -2 & $156.4 \pm 1.5$ & $155.7 \pm 3.3$ & 0 \\
\hline \multirow[t]{2}{*}{ Protein content } & Total & 159.8 & 152.2 & -5 & 205.8 & 208.7 & 1 \\
\hline & DON & $0.4 \pm 0.0$ & $2.8 \pm 0.9$ & - & $1.7 \pm 0.3$ & $10.3 \pm 0.7$ & - \\
\hline \multirow[t]{2}{*}{ Toxin $(\mathrm{mg} / \mathrm{kg})$} & 3-Ac-DON & $0.0 \pm 0.0$ & $0.1 \pm 0.0$ & - & $0.1 \pm 0.0$ & $0.6 \pm 0.0$ & - \\
\hline & Total & 0.4 & 2.9 & - & 1.8 & 10.9 & - \\
\hline
\end{tabular}

Table 2 Protein concentration $(\mathrm{g} / \mathrm{kg})$ in naturally and artificially Fusarium-infected grain from the emmer cultivar Far-108+Hein-101 and the relative variance between natural and artificial infection (\%) at the locations Sattenhausen and Reinshof as well as the DON and 3-Ac-DON concentration of the naturally and artificially infected grain

\begin{tabular}{|c|c|c|c|c|c|c|c|}
\hline \multirow{2}{*}{$\begin{array}{l}\text { Protein fractions } \\
(\mathrm{g} / \mathrm{kg})\end{array}$} & \multirow[t]{2}{*}{ Type } & \multicolumn{3}{|l|}{ Sattenhausen } & \multicolumn{3}{|l|}{ Reinshof } \\
\hline & & $\begin{array}{l}\text { Natural } \\
\text { infection }\end{array}$ & $\begin{array}{l}\text { Artificial } \\
\text { infection }\end{array}$ & $\begin{array}{l}\text { Variance natural } \\
\text { to artificial } \\
\text { infection }(\%)\end{array}$ & $\begin{array}{l}\text { Natural } \\
\text { infection }\end{array}$ & $\begin{array}{l}\text { Artificial } \\
\text { infection }\end{array}$ & $\begin{array}{l}\text { Variance natural } \\
\text { to artificial } \\
\text { infection }(\%)\end{array}$ \\
\hline \multirow[t]{3}{*}{ Albumins + globulins } & Total & $20.7 \pm 1.6$ & $20.5 \pm 2.2$ & -1 & $21.6 \pm 1.0$ & $21.8 \pm 0.6$ & 1 \\
\hline & Total & $87.1 \pm 4.1$ & $86.2 \pm 2.5$ & -1 & $112.7 \pm 1.0$ & $122.7 \pm 0.2$ & 9 \\
\hline & $\omega 5$ & $5.2 \pm 0.3$ & $5.0 \pm 0.1$ & -4 & $9.1 \pm 0.1$ & $10.3 \pm 0.3$ & 13 \\
\hline \multirow[t]{5}{*}{ Gliadins } & $\omega 1,2$ & $1.5 \pm 0.2$ & $1.5 \pm 0.3$ & 4 & $1.9 \pm 0.1$ & $2.4 \pm 0.3$ & 30 \\
\hline & $\alpha$ & $36.8 \pm 1.8$ & $36.3 \pm 1.0$ & -1 & $48.9 \pm 0.3$ & $53.7 \pm 0.4$ & 10 \\
\hline & $\gamma$ & $43.7 \pm 1.9$ & $43.4 \pm 1.0$ & -1 & $52.8 \pm 0.8$ & $56.3 \pm 0.8$ & 7 \\
\hline & Total & $15.7 \pm 0.3$ & $14.9 \pm 0.6$ & -5 & $24.8 \pm 0.9$ & $19.6 \pm 0.0$ & -21 \\
\hline & $\omega \mathrm{b}$ & $0.7 \pm 0.0$ & $0.7 \pm 0.0$ & 0 & $1.4 \pm 0.1$ & $1.1 \pm 0.1$ & -26 \\
\hline \multirow[t]{2}{*}{ Glutenins } & HMW-GS & $3.0 \pm 0.1$ & $2.7 \pm 0.1$ & -9 & $5.6 \pm 0.5$ & $4.1 \pm 0.1$ & -28 \\
\hline & LMW-GS & $12.0 \pm 0.4$ & $11.5 \pm 0.6$ & -4 & $17.8 \pm 0.5$ & $14.4 \pm 0.0$ & -19 \\
\hline Gluten & Total & $102.8 \pm 4.5$ & $101.1 \pm 3.0$ & -2 & $137.5 \pm 1.9$ & $142.3 \pm 0.2$ & 3 \\
\hline Gliadin/glutenin & Ratio & 5.5 & 5.8 & - & 4.5 & 6.3 & - \\
\hline Extract proteins & Total & $123.5 \pm 2.9$ & $121.6 \pm 0.8$ & -2 & $159.1 \pm 0.9$ & $164.1 \pm 0.8$ & 3 \\
\hline \multirow[t]{2}{*}{ Protein content } & Total & 150.4 & 152.9 & 2 & 209.6 & 211.1 & 1 \\
\hline & DON & $0.2 \pm 0.0$ & $1.1 \pm 0.0$ & - & $1.7 \pm 0.4$ & $5.2 \pm 0.7$ & - \\
\hline \multirow[t]{2}{*}{ Toxin $(\mathrm{mg} / \mathrm{kg})$} & 3-Ac-DON & $0.0 \pm 0.0$ & $0.0 \pm 0.1$ & - & $0.0 \pm 0.0$ & $0.4 \pm 0.0$ & - \\
\hline & Total & 0.2 & 1.1 & - & 1.7 & 5.5 & - \\
\hline
\end{tabular}


Table 3 Protein concentration $(\mathrm{g} / \mathrm{kg})$ in naturally and artificially Fusarium-infected grain from the emmer cultivar Klein and the relative variance between natural and artificial infection (\%) at the locations Sattenhausen and Reinshof as well as the DON and 3-Ac-DON concentration of the naturally and artificially infected grain

\begin{tabular}{|c|c|c|c|c|c|c|c|}
\hline \multirow{2}{*}{$\begin{array}{l}\text { Protein fractions } \\
(\mathrm{g} / \mathrm{kg})\end{array}$} & \multirow[t]{2}{*}{ Type } & \multicolumn{3}{|l|}{ Sattenhausen } & \multicolumn{3}{|l|}{ Reinshof } \\
\hline & & $\begin{array}{l}\text { Natural } \\
\text { infection }\end{array}$ & $\begin{array}{l}\text { Artificial } \\
\text { infection }\end{array}$ & $\begin{array}{l}\text { Variance natural } \\
\text { to artificial } \\
\text { infection }(\%)\end{array}$ & $\begin{array}{l}\text { Natural } \\
\text { infection }\end{array}$ & $\begin{array}{l}\text { Artificial } \\
\text { infection }\end{array}$ & $\begin{array}{l}\text { Variance natural } \\
\text { to artificial } \\
\text { infection }(\%)\end{array}$ \\
\hline \multirow[t]{3}{*}{ Albumins + globulins } & Total & $22.3 \pm 0.9$ & $21.8 \pm 2.5$ & -3 & $21.0 \pm 1.4$ & $21.1 \pm 0.8$ & 0 \\
\hline & Total & $81.1 \pm 0.4$ & $78.9 \pm 0.1$ & -3 & $103.8 \pm 3.6$ & $110.4 \pm 0.3$ & 6 \\
\hline & $\omega 5$ & $6.0 \pm 0.1$ & $6.0 \pm 0.1$ & -1 & $10.9 \pm 0.4$ & $12.2 \pm 0.1$ & 12 \\
\hline \multirow[t]{5}{*}{ Gliadins } & $\omega 1,2$ & $1.4 \pm 0.2$ & $1.6 \pm 0.013$ & $1.7 \pm 0.3$ & $2.0 \pm 0.1$ & 19 & \\
\hline & $\alpha$ & $36.7 \pm 0.0$ & $36.1 \pm 0.1$ & -2 & $47.0 \pm 0.8$ & $50.0 \pm 1.5$ & 6 \\
\hline & $\gamma$ & $37.0 \pm 0.3$ & $35.2 \pm 0.8$ & -5 & $44.2 \pm 2.2$ & $46.2 \pm 1.3$ & 5 \\
\hline & Total & $15.2 \pm 0.1$ & $13.3 \pm 0.3$ & -12 & $29.6 \pm 0.6$ & $22.8 \pm 0.2$ & -23 \\
\hline & $\omega \mathrm{b}$ & $0.6 \pm 0.0$ & $0.6 \pm 0.0$ & $01.6 \pm 0.3$ & $1.1 \pm 0.1$ & -28 & \\
\hline \multirow[t]{2}{*}{ Glutenins } & HMW-GS & $2.7 \pm 0.1$ & $2.1 \pm 0.0$ & -23 & $6.0 \pm 0.4$ & $4.6 \pm 0.3$ & -24 \\
\hline & LMW-GS & $11.9 \pm 0.2$ & $10.6 \pm 0.3$ & -11 & $22.0 \pm 0.8$ & $17.1 \pm 0.1$ & -22 \\
\hline Gluten & Total & $96.3 \pm 0.3$ & $92.2 \pm 0.4$ & -4 & $133.4 \pm 3.0$ & $133.2 \pm 0.4$ & 0 \\
\hline Gliadin/glutenin & Ratio & 5.4 & 6.0 & - & 3.5 & 4.8 & - \\
\hline Extract proteins & Total & $118.6 \pm 0.6$ & $114.0 \pm 2.9$ & -4 & $154.4 \pm 1.6$ & $154.3 \pm 1.3$ & 0 \\
\hline Protein content & Total & 159.8 & 156.2 & -2 & 196.1 & 205.6 & 5 \\
\hline DON & $0.7 \pm 0.1$ & $2.6 \pm 0.1$ & - & $1.8 \pm 0.1$ & $5.9 \pm 1.2$ & - & \\
\hline \multirow[t]{2}{*}{ Toxin $(\mathrm{mg} / \mathrm{kg})$} & 3-Ac-DON & $0.0 \pm 0.0$ & $0.1 \pm 0.0$ & - & $0.0 \pm 0.0$ & $0.2 \pm 0.0$ & - \\
\hline & Total & 0.7 & 2.7 & - & 1.8 & 6.1 & - \\
\hline
\end{tabular}

Table 4 Protein concentration $(\mathrm{g} / \mathrm{kg})$ in naturally and artificially Fusarium-infected grain from all three emmer cultivars (Far108+Hein-101, Klein, Linie 9-102) used in the study and the relative variance between natural and artificial infection (\%) at the locations Sattenhausen and Reinshof as well as the DON and 3-Ac-DON concentration of the naturally and artificially infected grain

\begin{tabular}{|c|c|c|c|c|c|c|c|}
\hline \multirow{2}{*}{$\begin{array}{l}\text { Protein fractions } \\
(\mathrm{g} / \mathrm{kg})\end{array}$} & \multirow[t]{2}{*}{ Type } & \multicolumn{3}{|l|}{ Sattenhausen } & \multicolumn{3}{|l|}{ Reinshof } \\
\hline & & $\begin{array}{l}\text { Natural } \\
\text { infection }\end{array}$ & $\begin{array}{l}\text { Artificial } \\
\text { infection }\end{array}$ & $\begin{array}{l}\text { Variance natural } \\
\text { to artificial } \\
\text { infection }(\%)\end{array}$ & $\begin{array}{l}\text { Natural } \\
\text { infection }\end{array}$ & $\begin{array}{l}\text { Artificial } \\
\text { infection }\end{array}$ & $\begin{array}{l}\text { Variance natural } \\
\text { to artificial } \\
\text { infection }(\%)\end{array}$ \\
\hline \multirow[t]{3}{*}{ Albumins + globulins } & Total & $21.5 \pm 1.0$ & $21.2 \pm 0.7$ & -1 & $21.7 \pm 0.7$ & $21.6 \pm 0.5$ & 0 \\
\hline & Total & $86.2 \pm 3.9$ & $84.8 \pm 4.7$ & -2 & $111.6 \pm 7.7$ & $117.6 \pm 6.4$ & 5 \\
\hline & $\omega 5$ & $5.1 \pm 1.1$ & $4.9 \pm 1.1$ & -3 & $9.1 \pm 1.7$ & $9.9 \pm 2.4$ & 9 \\
\hline \multirow[t]{5}{*}{ Gliadins } & $\omega 1,2$ & $1.3 \pm 0.3$ & $1.3 \pm 0.5$ & 2 & $1.7 \pm 0.2$ & $1.9 \pm 0.6$ & 13 \\
\hline & $\alpha$ & $37.5 \pm 1.1$ & $36.9 \pm 1.1$ & -1 & $50.2 \pm 4.2$ & $53.0 \pm 2.8$ & 6 \\
\hline & $\gamma$ & $42.3 \pm 4.5$ & $41.7 \pm 5.5$ & -2 & $50.6 \pm 5.7$ & $52.8 \pm 5.8$ & 4 \\
\hline & Total & $14.7 \pm 1.3$ & $13.1 \pm 1.9$ & -11 & $23.4 \pm 7.0$ & $18.8 \pm 4.5$ & -20 \\
\hline & $\omega \mathrm{b}$ & $0.5 \pm 0.2$ & $0.5 \pm 0.2$ & 0 & $1.2 \pm 0.5$ & $0.9 \pm 0.4$ & -28 \\
\hline \multirow[t]{2}{*}{ Glutenins } & HMW-GS & $2.5 \pm 0.7$ & $2.1 \pm 0.7$ & -16 & $4.8 \pm 1.8$ & $3.6 \pm 1.2$ & -24 \\
\hline & LMW-GS & $11.7 \pm 0.5$ & $10.5 \pm 1.0$ & -10 & $17.4 \pm 4.8$ & $14.3 \pm 2.9$ & -18 \\
\hline Gluten & Total & $100.9 \pm 3.2$ & $97.9 \pm 4.4$ & -3 & $135.0 \pm 2.0$ & $136.4 \pm 4.7$ & 1 \\
\hline Gliadin/glutenin & Ratio & 5.9 & 6.5 & - & 4.8 & 6.3 & - \\
\hline Extract proteins & Total & $122.4 \pm 2.4$ & $119.1 \pm 3.7$ & -3 & $156.7 \pm 2.3$ & $158.0 \pm 4.9$ & 1 \\
\hline \multirow[t]{2}{*}{ Protein content } & Total & 156.7 & 153.8 & -2 & 203.8 & 208.5 & 2 \\
\hline & DON & $0.5 \pm 0.3$ & $2.2 \pm 0.9$ & - & $1.7 \pm 0.0$ & $7.1 \pm 2.8$ & - \\
\hline \multirow[t]{2}{*}{ Toxin $(\mathrm{mg} / \mathrm{kg})$} & 3-Ac-DON & $0.0 \pm 0.0$ & $0.1 \pm 0.1$ & - & $0.1 \pm 0.1$ & $0.4 \pm 0.2$ & - \\
\hline & Total & 0.5 & 2.2 & - & 1.8 & 7.5 & - \\
\hline
\end{tabular}


Table 5 Protein concentration $(\mathrm{g} / \mathrm{kg})$ in naturally and artificially Fusarium-infected grain from the wheat cultivar Amaretto and the relative variance between natural and artificial infection (\%) at the locations Sattenhausen and Reinshof as well as the DON and 3-Ac-DON concentration of the naturally and artificially infected grain

\begin{tabular}{|c|c|c|c|c|c|c|c|}
\hline \multirow{2}{*}{$\begin{array}{l}\text { Protein fractions } \\
(\mathrm{g} / \mathrm{kg})\end{array}$} & \multirow[t]{2}{*}{ Type } & \multicolumn{3}{|l|}{ Sattenhausen } & \multicolumn{3}{|l|}{ Reinshof } \\
\hline & & $\begin{array}{l}\text { Natural } \\
\text { infection }\end{array}$ & $\begin{array}{l}\text { Artificial } \\
\text { infection }\end{array}$ & $\begin{array}{l}\text { Variance natural } \\
\text { to artificial } \\
\text { infection }(\%)\end{array}$ & $\begin{array}{l}\text { Natural } \\
\text { infection }\end{array}$ & $\begin{array}{l}\text { Artificial } \\
\text { infection }\end{array}$ & $\begin{array}{l}\text { Variance natural } \\
\text { to artificial } \\
\text { infection }(\%)\end{array}$ \\
\hline \multirow[t]{3}{*}{ Albumins + globulins } & Total & $23.4 \pm 0.4$ & $22.1 \pm 0.6$ & -6 & $23.4 \pm 0.3$ & $23.4 \pm 0.1$ & 0 \\
\hline & Total & $61.9 \pm 1.5$ & $65.9 \pm 0.6$ & 6 & $62.6 \pm 0.8$ & $73.2 \pm 0.5$ & 17 \\
\hline & $\omega 5$ & $2.7 \pm 0.1$ & $2.9 \pm 0.1$ & 7 & $3.1 \pm 0.1$ & $3.5 \pm 0.1$ & 12 \\
\hline \multirow[t]{5}{*}{ Gliadins } & $\omega 1,2$ & $5.7 \pm 0.5$ & $6.0 \pm 0.3$ & 6 & $6.8 \pm 0.2$ & $10.6 \pm 0.1$ & 57 \\
\hline & $\alpha$ & $22.5 \pm 0.8$ & $25.1 \pm 0.2$ & 11 & $23.7 \pm 0.7$ & $26.9 \pm 0.1$ & 14 \\
\hline & $\gamma$ & $31.0 \pm 0.1$ & $31.9 \pm 0.6$ & 3 & $29.0 \pm 0.2$ & $32.2 \pm 0.8$ & 11 \\
\hline & Total & $20.2 \pm 0.8$ & $11.6 \pm 0.5$ & -43 & $30.6 \pm 0.2$ & $17.0 \pm 0.2$ & -44 \\
\hline & $\omega \mathrm{b}$ & $0.7 \pm 0.1$ & $0.5 \pm 0.1$ & -36 & $0.8 \pm 0.1$ & $0.6 \pm 0.1$ & -31 \\
\hline \multirow[t]{2}{*}{ Glutenins } & HMW-GS & $5.0 \pm 0.1$ & $2.4 \pm 0.2$ & -53 & $9.3 \pm 0.4$ & $4.4 \pm 0.5$ & -52 \\
\hline & LMW-GS & $14.5 \pm 0.8$ & $8.7 \pm 0.3$ & -40 & $20.5 \pm 0.5$ & $12.0 \pm 0.3$ & -41 \\
\hline Gluten & Total & $82.1 \pm 0.8$ & $77.5 \pm 0.1$ & -6 & $94.2 \pm 0.8$ & $90.2 \pm 0.4$ & -4 \\
\hline Gliadin/glutenin & Ratio & 3.1 & 5.7 & - & 2.0 & 4.1 & - \\
\hline Extract proteins & Total & $105.5 \pm 0.4$ & $99.6 \pm 0.6$ & -6 & $116.6 \pm 0.5$ & $113.6 \pm 0.3$ & -3 \\
\hline \multirow[t]{2}{*}{ Protein content } & Total & 135.0 & 136.6 & 1 & 147.2 & 145.8 & -1 \\
\hline & DON & $0.3 \pm 0.0$ & $2.1 \pm 0.7$ & - & $0.0 \pm 0.0$ & $3.6 \pm 0.2$ & - \\
\hline \multirow[t]{2}{*}{ Toxin (mg/kg) } & 3-Ac-DON & $0.0 \pm 0.0$ & $0.1 \pm 0.0$ & - & $0.0 \pm 0.0$ & $0.1 \pm 0.0$ & - \\
\hline & Total & 0.3 & 2.2 & - & 0.0 & 3.7 & - \\
\hline
\end{tabular}

(Tables 1, 2, 3, 4; Fig. 2). In contrast to gliadin, the glutenin content in the artificially infected samples showed a significant reduction of its main subunits HMW-GS and LMW-GS in both the emmer (Table 6) and the summer wheat cultivar (Fig. 2). The glutenin-bound $\omega \mathrm{b}$-gliadins were also reduced, but not significantly. Therefore, we can conclude that a destruction of the glutenin fraction arises related to the infection (Table 4). A comparison between the results for emmer and wheat (Tables 4, 5; Fig. 2) indicates that the glutenin fractions and types are more strongly affected by Fusarium infection in wheat than in emmer in spite of the lower degree of infection found in the wheat.

Although the total gluten content did not change significantly, the ratio between gliadin and glutenin content changed according to the extent of the infection in favour of gliadin. The relationship between the ratios of emmer and wheat showed a twice as high ratio for emmer compared to wheat (Table 6). This result is confirmed by an earlier study on wheat which also described an increase in the gliadins and a decrease in glutenin content in this cereal [11]. The explanations given for this include that the changes in glutenin synthesis during the later stages of kernel maturation occur largely due to a reduced protein synthesis invoked by Fusarium infection and the inhibition of protein synthesis by the accumulation of DON $[5,8,11]$. In contrast, another study found no gliadin and glutenin monomer synthesis at different maturation stages; just polymeric glutenin formation was detected in the later stages [12].

For the present results, we have assumed an enzymatic degradation of the glutenin subunits by the fungal proteases. Such proteases of the Fusarium spp. exoproteome include trypsin-like protease or serine protease, which are known to be protein-degrading enzymes [24-26]. The fragments released by this degradation are most likely to be more soluble in $60 \%$ ethanol, so that we could identify the glutenin fragments during the extraction step for the gliadin fraction. This would have led finally to the higher gliadin and lower glutenin contents found in the artificially infected samples in comparison to the naturally infected samples (Tables 1, 2, 3, 4, 5, 6; Fig. 2) [26].

A comparison of the emmer and wheat also indicated that in spite of the stronger infection present in the emmer, the glutenin degradation was not as high as in wheat. The reasons for this effect may be the existence or higher expression of protease inhibitors (serine proteinase inhibitors) in emmer than in wheat [27].

Altogether, the comparison of the emmer and wheat gluten fractions showed that the gliadin fraction is the main fraction in both species (emmer: $71 \%$; wheat: $56 \%$ ), but that emmer had a $50 \%$ higher content than wheat. The 
Table 6 Summary of the protein concentration $(\mathrm{g} / \mathrm{kg})$ in naturally and artificially Fusarium-infected grain from all three emmer cultivars (Far-108+Hein-101, Klein, Linie 9-102) and the wheat cultivar Amaretto with the relative variance between natural and artificial infection
(\%) at both the Sattenhausen and Reinshof locations as well as the DON and 3-Ac-DON concentration of the naturally and artificially infected grain

\begin{tabular}{|c|c|c|c|c|c|c|c|c|}
\hline \multirow[t]{2}{*}{ Protein fractions $(\mathrm{g} / \mathrm{kg})$} & \multirow[t]{2}{*}{ Type } & \multicolumn{3}{|l|}{ Sattenhausen } & \multirow[t]{2}{*}{$p^{\#}$} & \multicolumn{3}{|l|}{ Reinshof } \\
\hline & & $\begin{array}{l}\text { Natural } \\
\text { infection }\end{array}$ & $\begin{array}{l}\text { Artificial } \\
\text { infection }\end{array}$ & $\begin{array}{l}\text { Variance natural } \\
\text { to artificial } \\
\text { infection }(\%)\end{array}$ & & $\begin{array}{l}\text { Natural } \\
\text { infection }\end{array}$ & $\begin{array}{l}\text { Artificial } \\
\text { infection }\end{array}$ & $\begin{array}{l}\text { Variance natural } \\
\text { to artificial } \\
\text { infection }(\%)\end{array}$ \\
\hline \multirow{3}{*}{ Albumins + globulins } & Total & $21.6 \pm 0.6$ & $21.4 \pm 0.5$ & -0.8 & 0.18 & $23.4 \pm 0$ & $22.7 \pm 0.8$ & -2.6 \\
\hline & Total & $98.9 \pm 14.3$ & $101.3 \pm 17.9$ & 2.4 & 0.25 & $62.2 \pm 0.41$ & $69.6 \pm 2.3$ & 11.8 \\
\hline & $\omega 5$ & $7.1 \pm 2.5$ & $7.4 \pm 3.1$ & 4.5 & 0.31 & $2.9 \pm 0.25$ & $3.2 \pm 0.4$ & 9.9 \\
\hline \multirow[t]{5}{*}{ Gliadins } & $\omega 1,2$ & $1.5 \pm 0.3$ & $1.6 \pm 0.6$ & 7.8 & 0.39 & $6.2 \pm 0.64$ & $8.3 \pm 2.7$ & 33.4 \\
\hline & $\alpha$ & $43.8 \pm 7.1$ & $45.0 \pm 8.6$ & 2.6 & 0.24 & $23.1 \pm 0.67$ & $26.0 \pm 1.0$ & 12.5 \\
\hline & $\gamma$ & $46.5 \pm 6.2$ & $47.3 \pm 7.6$ & 1.7 & 0.29 & $30.0 \pm 1.15$ & $32.1 \pm 0.1$ & 7.0 \\
\hline & Total & $19.1 \pm 6.3$ & $15.9 \pm 4.2$ & -16.3 & 0.02 & $25.5 \pm 6$ & $14.3 \pm 3.2$ & -43.9 \\
\hline & $\omega \mathrm{b}$ & $0.9 \pm 0.5$ & $0.7 \pm 0.3$ & -19.4 & 0.10 & $0.8 \pm 0.07$ & $0.5 \pm 0.1$ & -33.3 \\
\hline \multirow[t]{2}{*}{ Glutenins } & HMW-GS & $3.6 \pm 1.7$ & $2.9 \pm 1.2$ & -21.6 & 0.02 & $7.2 \pm 2.45$ & $3.4 \pm 1.2$ & -52.5 \\
\hline & LMW-GS & $14.6 \pm 4.2$ & $12.4 \pm 2.7$ & -14.8 & 0.03 & $17.5 \pm 3.48$ & $10.4 \pm 1.9$ & -40.8 \\
\hline Gluten & Total & $118.0 \pm 18.0$ & $117.2 \pm 20.5$ & -0.7 & 0.59 & $87.7 \pm 7.07$ & $83.9 \pm 5.5$ & -4.3 \\
\hline Gliadin/glutenin & Ratio & 5.2 & 6.4 & - & - & 2.4 & 4.9 & - \\
\hline Extract proteins & Total & $139.6 \pm 18.0$ & $138.6 \pm 20.7$ & -0.7 & 0.73 & $111.1 \pm 6.4$ & $106.6 \pm 6.3$ & -4.0 \\
\hline \multirow[t]{2}{*}{ Protein } & Total & 180.2 & 178.8 & -0.8 & 0.54 & 141.1 & 141.2 & 0.1 \\
\hline & DON & $1.1 \pm 0.7$ & $4.6 \pm 3.3$ & - & - & $0.2 \pm 0.0$ & $2.9 \pm 1.1$ & - \\
\hline \multirow[t]{2}{*}{ Toxin $(\mathrm{mg} / \mathrm{kg})$} & 3-Ac-DON & $0.0 \pm 0.0$ & $0.2 \pm 0.2$ & - & - & $0.0 \pm 0.0$ & $0.1 \pm 0.0$ & - \\
\hline & Total & 1.1 & 4.9 & - & - & 0.2 & 2.9 & - \\
\hline
\end{tabular}

\# $p$ significance of difference between natural and artificial infected emmer cultivars on both locations

Fig. 2 Variations in percent of protein fractions and types in the whole flour from the three emmer cultivars and the wheat cultivar from two growing locations after artificial Fusarium infection in comparison to natural infection

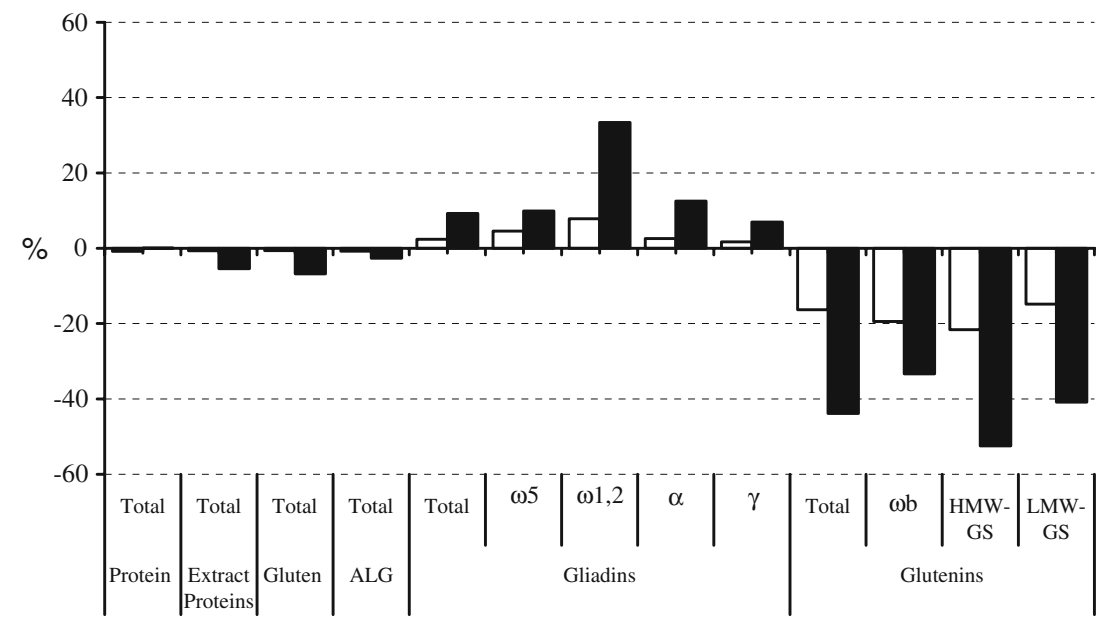

DEmmer Wheat glutenin fractions in emmer are present in the same quantities as in wheat (Tables 1, 2, 3, 4, 5, 6). The higher gliadin content in emmer found in this study may be a result of enhanced gene expression based on upstream factors of the gene, which result in a higher gliadin/glutenin ratio in comparison to wheat $[28,29]$.
Effect of $\mathrm{N}$ supply at two different locations on the protein content

The emmer cultivars showed at both locations ( $\mathrm{SH}$ and $\mathrm{RH}$ ) a $30 \%$ higher protein content than in the wheat (Tables 1, 2, 3, $4,5,6)$. The protein contents found in the emmer in this 
Fig. 3 Quantities of protein fractions in emmer $(n=3)$ and wheat cultivar at two locations (SHSattenhausen, $R H$ Reinshof) according to the $\mathrm{N}$ supply ( $\mathrm{RH}>\mathrm{SH})$; the significant changes for emmer are denoted as $p$ values

Fig. 4 Quantities of gliadin types in three emmer cultivars and a wheat cultivar at two locations (SH Sattenhausen, $R H$ Reinshof) dependent on the $\mathrm{N}$ supply $(\mathrm{RH}>\mathrm{SH})$; significant changes for emmer are denoted as $p$ values

Fig. 5 Quantities of glutenin types in emmer $(n=3)$ and wheat cultivar at two locations (SH Sattenhausen, RH Reinshof) dependent on $\mathrm{N}$ supply

( $\mathrm{RH}>\mathrm{SH}$ ); significant changes for emmer are denoted as $p$ values
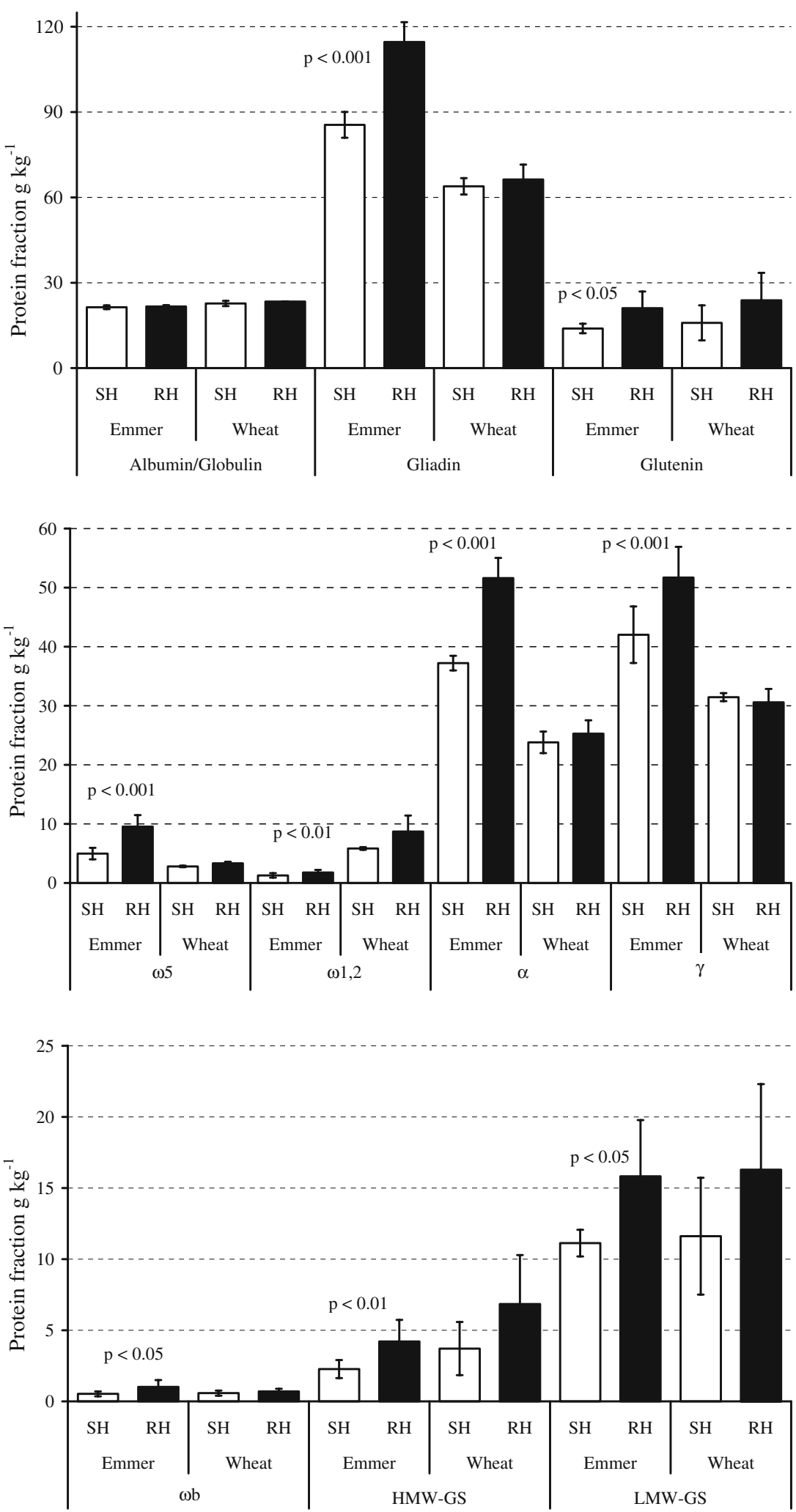

study were $2-7 \%$ higher than those found in the literature [9]. The total protein content in emmer seems to be significantly connected to the conditions present at the growing location (Figs. 3, 4, 5), which is supported by the results of the investigated wheat cultivar. The results for the wheat in this investigation confirm the results from a previous study [19].

For the impact of the location on the extracted protein fractions in emmer and wheat, we considered both the 
Table 7 Fusarium protein units (FPU) in naturally and artificially Fusarium-infected grain flour (summarized data from both locations)

\begin{tabular}{llll}
\hline Species & Cultivar & \multicolumn{2}{l}{ FPU $(\mathrm{g} / \mathrm{kg})$} \\
\cline { 3 - 4 } & & Natural infection & Artificial infection \\
\hline Emmer & Linie 9-102 & $0.01 \pm 0.01$ & $0.13 \pm 0.16$ \\
& Far-108+Hein-101 & $0.01 \pm 0.01$ & $0.19 \pm 0.27$ \\
& Klein & $0.00 \pm 0.00$ & $0.22 \pm 0.25$ \\
& $n=3$ & $0.01 \pm 0.01$ & $0.18 \pm 0.18$ \\
Wheat & Amaretto & $0.00 \pm 0.00$ & $0.43 \pm 0.02$ \\
\hline
\end{tabular}

Table 8 Variance of the relative protein concentration between the two locations, Sattenhausen and Reinshof, from the three emmer cultivars (Far-108+Hein-101, Klein, Linie 9-102) and the wheat cultivar Amaretto dependent on $\mathrm{N}$ supply

\begin{tabular}{lllc}
\hline Protein fractions & Type & Emmer $(n=3)$ & Wheat $(n=1)$ \\
\hline Albumin/globulin & Total & 1.1 & 3.0 \\
& Total & 34.1 & 3.7 \\
& $\omega 5$ & 91.6 & 18.6 \\
Gliadins & $\omega 1,2$ & 38.4 & 49.0 \\
& $\alpha$ & 38.7 & 6.2 \\
& $\gamma$ & 23.1 & -2.8 \\
& Total & 51.1 & 49.9 \\
Glutenins & $\omega b$ & 93.1 & 21.2 \\
\multirow{3}{*}{ Gluten } & HMW-GS & 85.1 & 84.5 \\
Extract proteins & TMW-GS & 42.1 & 40.2 \\
Protein & Total & 36.5 & 13.6 \\
\hline
\end{tabular}

naturally and artificially fungal-infected samples together. The emmer showed a $30 \%$ and wheat an $8 \%$ higher total protein content at RH than at SH (Table 8). The percentage distribution of the different proteins showed that the gluten content rose but the amount of albumins and globulins was just marginally affected by the location-the total content in $\mathrm{g} / \mathrm{kg}$ was only changed by about $1-3 \%$ (Table 8 ; Fig. 3 ). This effect has also been described for wheat in the literature $[15,28]$. Albumins and globulins are mainly metabolic and structural proteins [30] and have functions in cell metabolism. There is a minimum amount of these compounds needed for these functions, but no increase in content occurs with respect to the $\mathrm{N}$ supply.

The gliadin content $(\mathrm{g} / \mathrm{kg})$ in emmer changed significantly (Fig. 3): at RH 36\% more gliadin was found in the grain than at $\mathrm{SH}$ and the glutenin content was also about $50 \%$ higher at RH (Table 8). Comparing the emmer to wheat, it can be said that the emmer storage proteins were more affected by the $\mathrm{N}$ supply at the location than wheat as the gliadin fraction in wheat was not or just minimally affected (Fig. 4; Table 8). In contrast, the wheat's glutenin fraction was affected in the same range as in the emmer (Fig. 5; Table 8). A consequence of these species-specific changes on the gluten fractions according to $\mathrm{N}$ supply is that the gliadin/glutenin ratio in wheat is more affected than in emmer (Tables 4,5 ), which could result in positive effects on its bread-making quality $[28,31]$. The reason for this difference in sensibility to $\mathrm{N}$ supply is possibly due to a regulation of synthesis. $\mathrm{N}$ availability and the resulting higher total protein content have been documented as a factor that can promote gene expression in other cereals such as wheat or maize [29]. Hypothetically, raised $\mathrm{N}$ levels in emmer cultivars lead to a more enhanced gene expression of the storage proteins than in wheat.

\section{Conclusions}

Emmer, normally grown under organic farming conditions, showed similar characteristics to wheat cultivars in their response to Fusarium spp. infection. In addition to the basic findings, new cognitions on the degradation and changes of protein subunits were found. Therefore, further investigations with a greater focus on protein degradation can be recommended. The influence of the growing location on cereal protein content has been well-documented in previous studies on wheat. The present results showed that this is also true in emmer, although there were differences between emmer and wheat. Further studies in this context may clarify the mechanisms that lead to the irregular synthesis of emmer protein subunits in comparison to wheat as a result of a mixed Fusarium infection and differing nitrogen availability.

Acknowledgments This work is part of the FAEN Joint Project 3 "Quality-related plant production under modified basic conditions: mycotoxins in the context of production, quality and processing", financed by the Ministry of Science and Culture of Lower Saxony, Germany. A special thanks is given to the growers who provided the seeds for this research trial: Dr. Karl-Josef Müller, Getreidezüchtungsforschung Darzau; Eckard Irion, Verein für Pflanzenzucht Hof Grub e.V.; Claus Einfeldt, Saatzucht Ackermann. Further thanks is extended to Hans-Werner Klein for the toxin analysis by the group of Prof. Petr Karlovsky, and especially to Sasithorn Limsuwan, Molecular Phytopathology and Mycotoxin Research, Department of Crop Science, Georg-August University Goettingen; as well as to Dr. Joachim Weinert, Department of Crop Science, Georg-August University Goettingen for the Biotin/Avidin ELISA and Alexandra Axthelm for HPLC protein analysis.

Open Access This article is distributed under the terms of the Creative Commons Attribution Noncommercial License which permits any noncommercial use, distribution, and reproduction in any medium, provided the original author(s) and source are credited. 


\section{References}

1. Bottalico A, Perrone G (2002) Toxigenic Fusarium species and mycotoxins associated with head blight in small-grain cereals in Europe. Eur J Plant Pathol 108:611-624

2. Buerstmayr H, Stierschneider M, Steiner B, Lemmens M, Griesser M, Nevo E, Fahima T (2003) Variation for resistance to head blight caused by Fusarium graminearum in wild emmer (Triticum dicoccoides) originating from Israel. Euphytica 130:17-23

3. Ramirez ML, Reynoso MM, Farnochi MC, Chulze S (2006) Vegetative compatibility and mycotoxin chemotypes among Fusarium graminearum (Gibberella zeae) isolates from wheat in Argentina. Eur J Plant Pathol 115:139-148

4. Yang L, van der Lee T, Yang X, Yu D, Waalwijk C (2008) Fusarium populations on chinese barley show a dramatic gradient in mycotoxin profiles. Phytopathology 98:719-727

5. Eriksen GS, Pettersson H (2004) Toxicological evaluation of trichothecenes in animal feed. Anim Feed Sci Technol 114:205-239

6. Thuvander A, Wikman C, Gadhasson I (1999) In vitro exposure of human lymphocytes to trichothecenes: individual variation in sensitivity and effects of combined exposure on lymphocyte function. Food Chem Toxicol 37:639-648

7. Tsuda S, Kosaka Y, Murakami M, Matsuo H, Matsusaka N, Taniguchi K, Sasaki YF (1998) Detection of nivalenol genotoxicity in cultured cells and multiple mouse organs by the alkaline single-cell gel electrophoresis assay. Mutat Res Genet Toxicol Environ Mutagen 415:191-200

8. Yabe T, Hashimoto H, Sekijima M, Degawa M, Hashimoto Y, Tashiro F, Ueno Y (1993) Effects of nivalenol on hepatic drugmetabolizing activity in rats. Food Chem Toxicol 31:573-581

9. Wieser $\mathrm{H}$ (2000) Comparative investigations of gluten proteins from different wheat species. I. Qualitative and quantitative composition of gluten protein types. Eur Food Res Technol 211:262-268

10. Boyacioglu D, Hettiarachchy NS (1995) Changes in some biochemical-components of wheat-grain that was infected with Fusarium graminearum. J Cereal Sci 21:57-62

11. Wang JH, Wieser H, Pawelzik E, Weinert J, Keutgen AJ, Wolf GA (2005) Impact of the fungal protease produced by Fusarium culmorum on the protein quality and breadmaking properties of winter wheat. Eur Food Res Technol 220:552-559

12. Abonyi T, Kiraly I, Tomoskozi S, Baticz O, Guoth A, Gergely S, Scholz E, Lasztity D, Lasztity R (2007) Synthesis of gluten-forming polypeptides. 1. Biosynthesis of gliadins and glutenin subunits. J Agric Food Chem 55:3655-3660

13. Prange A, Modrow H, Hormes J, Kramer J, Kohler P (2005) Influence of mycotoxin producing fungi (Fusarium, Aspergillus, Penicillium) on gluten proteins during suboptimal storage of wheat after harvest and competitive interactions between field and storage fungi. J Agric Food Chem 53:6930-6938

14. Benetrix F, Sarrafi A, Autran JC (1994) Effects of genotype and nitrogen nutrition on protein aggregates in barley. Cereal Chem $71: 75-82$

15. Pechanek U, Karger A, Groger S, Charvat B, Schoggl G, Lelley T (1997) Effect of nitrogen fertilization on quantity of flour protein components, dough properties, and breadmaking quality of wheat. Cereal Chem 74:800-805
16. Ndong C, Danyluk J, Wilson KE, Pocock T, Huner NPA, Sarhan F (2002) Cold-regulated cereal chloroplast late embryogenesis abundant-like proteins. Molecular characterization and functional analyses. Plant Physiol 129:1368-1381

17. Adejumo TO, Hettwer U, Karlovsky P (2007) Occurrence of Fusarium species and trichothecenes in Nigerian maize. Int J Food Microbiol 116:350-357

18. Tian SM, Wolf GA, Weinert J (2005) Accurate assessment of wheat and triticale cultivar resistance to Septoria tritici and Stagonospora nodorum infection by biotin/avidin ELISA. Plant Dis 89:1229-1234

19. Wieser H, Antes S, Seilmeier W (1998) Quantitative determination of gluten protein types in wheat flour by reversed-phase highperformance liquid chromatography. Cereal Chem 75:644-650

20. van Eckert R, Berghofer E, Ciclitira PJ, Chirdo F, Denery-Papini S, Ellis HJ, Ferranti P, Goodwin P, Immer U, Mamone G, Mendez E, Mothes T, Novalin S, Osman A, Rumbo M, Stern M, Thorell L, Whim A, Wieser H (2006) Towards a new gliadin reference material-isolation and characterisation. J Cereal Sci 43:331-341

21. Oliver RE, Stack RW, Miller JD, Cai X (2007) Reaction of wild emmer wheat accessions to Fusarium head blight. Crop Sci 47:893-899

22. Gottlieb DM, Schultz J, Bruun SW, Jacobsen S, Sondergaard I (2004) Multivariate approaches in plant science. Phytochemistry 65:1531-1548

23. Canovas FM, Dumas-Gaudot E, Recorbet G, Jorrin J, Mock HP, Rossignol M (2004) Plant proteome analysis. Wiley-VCH Verlag Gmbh, pp 285-298

24. Phalip V, Delalande F, Carapito C, Goubet F, Hatsch D, LeizeWagner E, Dupree P, Van Dorsselaer A, Jeltsch JM (2005) Diversity of the exoproteome of Fusarium graminearum grown on plant cell wall. Curr Genet 48:366-379

25. Pekkarinen A, Mannonen L, Jones BL, Niku-Paavola ML (2000) Production of proteases by Fusarium species grown on barley grains and in media containing cereal proteins. J Cereal Sci 31:253-261

26. Pekkarinen AI, Jones BL (2002) Trypsin-like proteinase produced by Fusarium culmorum grown on grain proteins. J Agric Food Chem 50:3849-3855

27. Pekkarinen AI, Longstaff C, Jones BL (2007) Kinetics of the inhibition of Fusarium serine proteinases by barley (Hordeum vulgare L.) inhibitors. J Agric Food Chem 55:2736-2742

28. Johansson E, Prieto-Linde ML, Jonsson JO (2001) Effects of wheat cultivar and nitrogen application on storage protein composition and breadmaking quality. Cereal Chem 78:19-25

29. Shewry PR, Halford NG (2002) Cereal seed storage proteins: structures, properties and role in grain utilization. J Exp Bot 53:947-958

30. Merlino M, Leroy P, Chambon C, Branlard G (2009) Mapping and proteomic analysis of albumin and globulin proteins in hexaploid wheat kernels (Triticum aestivum L.). Theor Appl Genet 118:1321-1337

31. Uthayakumaran S, Gras PW, Stoddard FL, Bekes F (1999) Effect of varying protein content and glutenin-to-gliadin ratio on the functional properties of wheat dough. Cereal Chem 76:389-394 